\title{
Efficient micropropagation of Dendrobium aurantiacum from shoot explant
}

\author{
Nyuk Ling $\mathrm{Ma}^{{ }^{*}}$, Shing Ching Khoo ${ }^{1}$, Jia Xi Lee ${ }^{1}$, Chin Fhong Soon ${ }^{2}$, Nor Aini AB Shukor ${ }^{3,4}$ \\ ${ }^{1}$ Faculty of Science and Marine Environment, Universiti Malaysia Terengganu, 21030 Kuala Terengganu, Malaysia \\ ${ }^{2}$ Microelectronics \& Nanotechnology - Shamsudin Research Centre (MiNT-SRC), Institute for Integrated Engineering, Universiti Tun Hussein \\ Onn Malaysia, 86400 Parit Raja, Malaysia \\ ${ }^{3}$ Institute of Tropical Forestry and Forest Products, Universiti Putra Malaysia, 43400 Serdang, Selangor, Malaysia \\ ${ }^{4}$ Faculty of Forestry, Universiti Putra Malaysia, 43400, Serdang, Selangor, Malaysia \\ *Email: nyukling@umt.edu.my
}

\section{ARTICLE HISTORY}

Received: 05 January 2020

Accepted: 11 March 2020

Published: 09 August 2020

KEYWORDS

Orchid

In vitro culture

Somatic embryogenesis

Sterilization

Callus

\section{ABSTRACT}

Embryogenic tissue culture (seed tissue culture) is a common practice in plant industry to speed up and mass production. However, the culture method is not widely adopted in most of the orchid species. Micro-size orchid seeds are difficult to obtain and collect due to ambiguous seed maturation period. Most of orchid seeds have no endosperm and highly dependent on the specific fungi for germination and survival. Micropropagation from shoot culture with meristem tissue is potentially be another alternative for mass propagation of orchid. Therefore, this study examine the potential of micropropagation technique by shoot culture in orchid, Dendrobium aurantiacum (F. Muell.) F. Muell. This study reported an effective aseptic technique to develop sterilized $D$. aurantiacum tissue in vitro. The callus induction and regeneration from shoot explant by utilization of different plant growth regulator had been examined in this study. Among the treatments, $20 \%$ sodium hypochlorite with 15 mins sterilization period showed the highest sterilization efficiency on explants with only $16.7 \pm 5.8 \%$ of contamination occurred after two weeks and obtained highest survival rate $73.3 \pm 5.8 \%$ after one month. Callus formed in all combinations of plant hormone treatments. Media treated with $10 \mathrm{mg} / \mathrm{L}$ 2,4-D showed the highest callus induction rate but browning condition occur after 3 months of culture. Cell count on callus proliferation showed a significant difference $(p<0.05)$ between control and treatments. In conclusion, micropropagation of $D$. aurantiacum had been shortened almost 9-12 months required for nature germination.

\section{Introduction}

Orchids are widely cultured for horticulture and medical purposes. Apart of its ornamental value, orchids has wide application such as raw material for production of medicine, facial beauty products and foods, orchids are thus had high trade market domestically and internationally (1, 2). Dendrobium orchids are one of the genus that are popular for its commercial and medical values in cut and potted flower industries (3). Dendrobium aurantiacum (F. Muell.) F. Muell. also known as "Shihu" or "Huangcao" in China province and it is widely distributed in temperated and tropical regions such as Southern China, South Asia, Taiwan, Laos and
Burma. Dendrobium aurantiacum is a growing lithophyte or epiphyte orchid that owned size ranged from a medium to large size (4). Dendrobium aurantiacum is a medicinal orchid which play an important role in traditional Chinese medicine for cough relief with lung moisturizing, immunomodulatory effects, antipyretic and antiaging effects (5). The species contained a variety of secondary metabolites such as phenolic compounds (phenanthrenes, bibenzyls, fluorenones), alkaloids, anthraquinones and sesquiterpenes (6).

However, orchids are often grown in low densities in nature and possess a long life cycle, especially during seed germination. Many orchids

(c) Ma et al (2020). This is an open-access article distributed under the terms of the Creative Commons Attribution License, which permits unrestricted use, distribution and reproduction in any medium, provided the original author and source are credited (https://creativecommons.org/licenses/by/4.0/).

To cite this article: Ma N L, Khoo S C, Lee J X, Soon C F, Shukor N A AB. Efficient micropropagation of Dendrobium aurantiacum from shoot explant. Plant Science Today. 2020;7(3):476-482. https://doi.org/10.14719/pst.2020.7.3.724 
take up to 5-7 years from seed to flowering stage and some hybrid orchids are about 3 years to complete growing process (7). Seed contained endosperms that serve as important food storage especially for the seed germination and protocorm development before the seed can carried out photosynthesis process. However, majority of the orchid seeds are lacking endosperms. Therefore, they are very much depended on specific fungal associations for germination and food supply. Due to the extremely specific symbiotic relationship, orchids are difficult to germinate and thus having a very low germination rate (8). With the introduction of plant tissue culture technique, the need of mycorrhiza symbiotic is eliminated and hence orchids can be massively propagated in vitro. This is advantageous to pharmaceutical industry that use orchids as raw material in bulk quantity.

Plant tissue culture is one of the plant biotechnology techniques used for the mass propagation of plants with the utilization of totipotency and high plasticity properties of plant cell (9). Callus formation and callus regeneration are the special abilities of plants to rebuild themselves after injury. This developmental plasticity is existing only in some animals' and it is remarkable in most of the plants. A complete plant can be constructed starting from a single cell. Micropropagation has several important uses in the production and conservation of rare, endangered, threatened, economically important and disease-free orchid species that are difficult to propagate through traditional horticultural methods (10). As orchids require long maturity time to blossom, micropropagation supports the regeneration from various vegetative parts of mature plants. In fact, by repeated sectioning and subculture, millions of plants can be produced from a single bud within one year (11).

Plant micropropagation is extremely efficient for the synthesis of high-quality plant based pharmaceutical products. The most common explant used in plant tissue culture was embryogenic germination with the use of seed. However, the problem faced by orchid species was the difficulty in obtaining dust-like seed as the seed collection is highly associated with the flowering season and it's also very time-consuming. Therefore, in this study, we focused to examine the use of shoot as explant for micropropagation and further explore its potential to grow and its interaction with plant growth regulators. This study could provide optimum sterilisation method for plant tissue culture and useful data for the effect of plant hormones on callus induction and regeneration of $D$. aurantiacum.

\section{Materials and Methods}

\section{Chemical List}

The sterilization agents used 70\% ethanol (diluted from 95\% ethanol, Universal Science Trading), Clorox household bleaching agent $(6.0 \%$ sodium hypochlorite) and commercial detergent (Decons 90). The chemical used for media preparation including
$\mathrm{KNO}_{3}, \quad \mathrm{NH}_{4} \mathrm{NO}_{3}, \quad \mathrm{MgSO}_{4} \cdot 7 \mathrm{H}_{2} \mathrm{O}, \quad \mathrm{CaCl}_{2} . \quad 2 \mathrm{H}_{2} \mathrm{O}$, $\mathrm{NaHPO}_{4} \cdot 2 \mathrm{H}_{2} \mathrm{O}, \quad \mathrm{H}_{3} \mathrm{BO}_{4}, \quad \mathrm{MnSO}_{4} \cdot \mathrm{H}_{2} \mathrm{O}, \quad \mathrm{ZnSO}_{4} .7 \mathrm{H}_{2} \mathrm{O}$, $\mathrm{Na}_{2} \mathrm{MoO}_{4} .2 \mathrm{H}_{2} \mathrm{O}, \mathrm{CuSO}_{4} .5 \mathrm{H}_{2} \mathrm{O}, \mathrm{CoCl}_{2} .6 \mathrm{H}_{2} \mathrm{O}, \mathrm{KI}, \mathrm{FeEDTA}$, myo-inositol, Thiamine-HCl, Pyrodoxine, Nicotinic Acid, Sucrose, and Phytagel. The plant growth regulator (PGR) used is 2,4-Di-chlorophenoxy-acetic acid (2,4-D) and Kinetin (6-furfuryl aminopurine, KIN). All the media preparation chemical and PGR used are purchased from Sigma- Aldrich (M) Sdn Bhd.

\section{Orchid Sources}

Orchid Dendrobium aurantiacum was selected in this study. D. aurantiacum was also known as $D$. denneanum, had been listed in Taxonomy ID 181002 in the NCBI Taxonomy (12). D. aurantiacum is widely distributed in Southern China, South Asia, Laos and
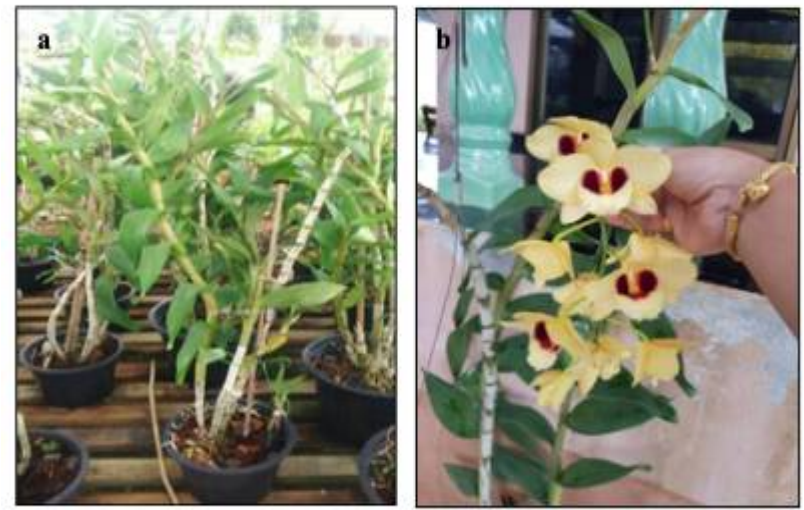

Fig. 1. Dendrobium aurantiacum orchid. 1a: the whole plant. 1b: flower.

Burma (5). The plants were collected from Nurseri Harapan, Terengganu, Malaysia with a GPS coordinate of $5^{\circ} 16^{\prime} 03.6 \mathrm{~N}, 103^{\circ} 10^{\prime} 35.2^{\prime} \mathrm{E}$ (Fig. 1). The plants were kept in the greenhouse prior to shoot cutting for tissue culture.

\section{Optimization of Sterilization Technique}

Orchid shoot was used as explant for tissue culture. The shoots of explant were excised cut at region between nodes. The white external layer of dead cells around the shoot explants were rubbed with hand and immersed in commercial detergent

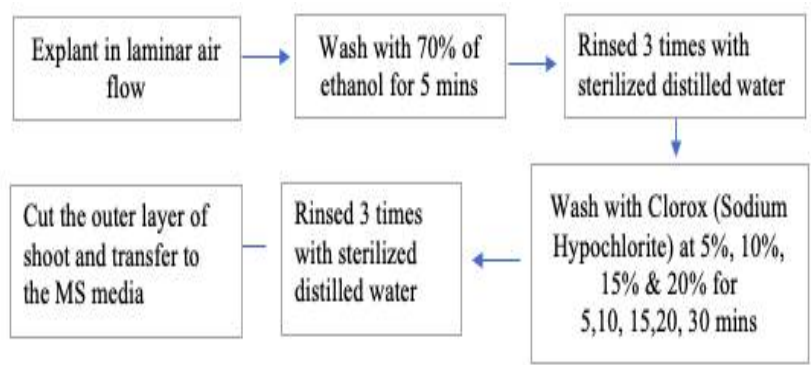

Fig. 2. The flowchart showing overall experimental design for the optimization of sterilization process.

(Decons 90) for 30 mins. The explants were then rinsed with running tap water for another 15 mins and subsequently washed with double sterilization agent (70\% ethanol and Clorox bleaching agent). The experimental design was set as in Fig. 2. There are 30 replicate for each treatment in order to test the optimal sterilization effect in orchid shoot explant. 
The optimization of sterilization was observed based on the contamination rate after 2 weeks, survival rate after one month and browning rate of the shoot explant.

\section{Media Preparation}

Murashige and Skoog medium (MS medium) was were prepared based on the specific formulation composition for callus induction and proliferation (13). M3S mixture was then added with $2.5 \mathrm{~g} / \mathrm{L}$ of phytagel to solidify the medium. The $\mathrm{pH}$ of the medium was then adjusted to $\mathrm{pH} 5.7 \pm 0.2$ and well mixed with hot plate stirred. The MS media is then sterilized at $121{ }^{\circ} \mathrm{C}$ for $15 \mathrm{~min}$ in an autoclave

Table 1. Media treatment for callus induction and callus proliferation

\begin{tabular}{clc}
$\begin{array}{c}\text { Treat } \\
\text { ment }\end{array}$ & Callus induction & References \\
\hline $\mathrm{A}$ & MS (Control) & $(8)$ \\
\hline $\mathrm{B}$ & $\mathrm{MS}+1.0 \mathrm{mg} / \mathrm{L} \mathrm{2,4-D}+0.5 \mathrm{mg} / \mathrm{L} \mathrm{KIN}$ & $(26)$ \\
\hline $\mathrm{C}$ & $\mathrm{MS}+10.0 \mathrm{mg} / \mathrm{L} \mathrm{2,4-D}$ & $(19)$ \\
\hline $\begin{array}{l}\text { Note: } \\
\text { represent kinetin. }\end{array}$
\end{tabular}

(Hirayama HVE-50 series, Amerex Instruments, Inc). Plant hormone (Table 1) was added into the media once the temperature had been cooled down to 50$60{ }^{\circ} \mathrm{C}$. The media were poured into petri dish in the laminar air flow chamber BBS-V1300/1800 (Biobase Biodustry Co., Ltd).

\section{Callus Induction and Callus Proliferation}

Plant hormone were used to initiation the formation of mass of differentiate cells called callus by using different concentration or types of hormones. In this study, three treatments had been tested for shoot induction of Dendrobium aurantiacum (Table 1). The orchid explants was sub-cultured every one month with the same hormone treatment for the callus proliferation. The observation parameters such as callus formation period, callus induction rate, colour of callus formation, callus type and browning condition had been observed and recorded after one month period of the callus.

\section{Cell count}

For better understanding on the effect of hormone to the callus proliferation rate, cell count in liquid suspension culture had been performed. The callus obtained in the agar plate were transferred into liquid MS media with the same hormone treatment as in Table 1 in $100 \mathrm{ml}$ conical flask and allow evenly agitated with the orbital shaker for one week period. The concentration of callus cell in each treatment were measured using automated cell counter (Thermofisher) on Day 1 and Day 7.

\section{Somatic Embryogenesis}

The somatic embryo of Dendrobium aurantiacum at different growth stage was observed in the light microscope. A $5 \mathrm{ml}$ volume of cells from liquid suspension culture were pipetted and transferred into a glass slide and then covered with cover slip. The glass slide was then observed under light microscope. The observation was carried out every week to check the somatic embryo process.

\section{Data Analysis}

The sterilization and callus proliferation data were subjected to analysis of variance (ANOVA) using Statistical Package for Social Science (SPSS) Version 20. Significant difference between the treatments were analysed by ANOVA and Post Hocs Tukey test for comparison by mean values of treatment $\mathrm{p}<0.05$. The homogenous subset group of each treatment have determined from SPSS and labelled with small letter of alphabets.

\section{Result and Discussion}

\section{Optimization of Sterilization Effect of Clorox Sterilization Agent}

The contamination rate of explants after two weeks and the survival rate of explants after 1 month were recorded (Table 2). During cultural transfers, dust particles containing microorganisms are continuously contact with cultural media, which act as enrich resources that promote their flourishing growth (14). Hence, endogenous microbial contamination may occur easily if proper sterilization techniques does not adopted.

The optimal sterilization requirements of shoot explant was ethanol $70 \%$ for $5 \mathrm{~min}$ following to $20 \%$ clorox for 15 mins, with approximately $83.3 \%$ and no browning condition observed on the explants. Commercial clorox contained sodium hypochlorite ( $\mathrm{NaOCl}$ had been widely known as cheap and efficient universal disinfectant in plant tissue culture. $\mathrm{NaOCl}$ can dissolved in water to produce $\mathrm{HOCl}$ and $\mathrm{OCl}^{-}$ions. The molecular form of $\mathrm{HOCl}$ can destroy the microorganisms and pathogens by penetrating their cell walls, breaking their slimy and protective layers, and finally resulting in reproductive failure $(15,16)$. Therefore, direct contact of the explant with the disinfectant during sterilization will increases the percentage of sterile culture (17). Low contamination rate of explants were observed with high dose of sodium hypochlorite. Due to rapid degradation, small dose of sodium hypochlorite does not cause toxicity to shoot explants (18). Nevertheless, the concentration of Clorox should be kept in the lowest possible rate because our result also show that high concentration of Clorox even provide higher sterilization efficiency but have negatively causing browning on plant cells that lead to poor survival rate.

\section{Effect of Hormone on Callus Induction and Proliferation of Dendrobium aurantiacum}

Since auxin could benefit to the callus induction, the effect of applying high amount of 2,4-D, and the combination of 2,4-D with KIN were examined (Table 3 ). Callus were $100 \%$ successfully induced from all the media combination (Fig. 3). The results showed that treatment $\mathrm{C}$ required the shortest time for callus formation where tiny callus started to develop at 3 days under stereomicroscope observation, followed by treatment $\mathrm{B}$ and $\mathrm{A}$, which took 5 and 7 days respectively (Fig. 3). White, compact and hard-textured callus was found in all the control and treatments. After three months observation, there were no 
Table 2. Sterilization effect of chlorox on the shoot explant of $D$. aurantiacum

\begin{tabular}{|c|c|c|c|c|c|}
\hline Treatment & Chlorox concentration (\%) & $\begin{array}{l}\text { Time } \\
\text { (min) }\end{array}$ & $\begin{array}{c}\text { Contamination } \\
\text { Rate (\%) }\end{array}$ & $\begin{array}{c}\text { Survival Rate after one } \\
\text { month (\%) }\end{array}$ & $\begin{array}{c}\text { Browning rate } \\
(\%)\end{array}$ \\
\hline $\mathrm{T} 1$ & & 5 & $100.00^{\mathrm{a}}$ & $0.0^{\mathrm{a}}$ & $0.0^{\mathrm{a}}$ \\
\hline $\mathrm{T} 2$ & & 10 & $86.7 \pm 11.5^{\mathrm{a}, \mathrm{b}}$ & $10.0 \pm 0.1^{\mathrm{a}, \mathrm{b}}$ & $0.0^{\mathrm{a}}$ \\
\hline T3 & 5 & 15 & $46.7 \pm 20.8^{\mathrm{b}, \mathrm{c}, \mathrm{d}}$ & $43.3 \pm 15.2^{\mathrm{b}, \mathrm{c}, \mathrm{d}}$ & $0.0^{\mathrm{a}}$ \\
\hline $\mathrm{T} 4$ & & 20 & $53.7 \pm 11.5^{\mathrm{a}, \mathrm{b}, \mathrm{c}, \mathrm{d}}$ & $26.7 \pm 25.2^{\mathrm{a}, \mathrm{b}, \mathrm{c}}$ & $0.0^{\mathrm{a}}$ \\
\hline $\mathrm{T} 5$ & & 30 & $46.7 \pm 5.8^{\mathrm{c}, \mathrm{d}}$ & $53.3 \pm 20.8^{\mathrm{c}, \mathrm{d}}$ & $0.0^{\mathrm{a}}$ \\
\hline T6 & & 5 & $73.3 \pm 25.2^{\mathrm{a}, \mathrm{b}, \mathrm{c}}$ & $26.7 \pm 25.2^{\mathrm{a}, \mathrm{b}, \mathrm{c}}$ & $0.0^{\mathrm{a}}$ \\
\hline $\mathrm{T} 7$ & & 10 & $56.7 \pm 15.3^{\mathrm{b}, \mathrm{c}, \mathrm{d}}$ & $43.3 \pm 15.3^{b, c, d}$ & $0.0^{\mathrm{a}}$ \\
\hline $\mathrm{T} 8$ & 10 & 15 & $66.7 \pm 5.8^{\mathrm{a}, \mathrm{b}, \mathrm{c}, \mathrm{d}}$ & $26.7 \pm 11.5^{\mathrm{a}, \mathrm{b}, \mathrm{c}}$ & $0.0^{\mathrm{a}}$ \\
\hline T9 & & 20 & $56.7 \pm 11.5^{b, c, d}$ & $33.3 \pm 11.5^{\mathrm{a}, \mathrm{b}, \mathrm{c}, \mathrm{d}}$ & $0.0^{\mathrm{a}}$ \\
\hline $\mathrm{T} 10$ & & 30 & $46.7 \pm 15.3^{\mathrm{c}, \mathrm{d}}$ & $46.7 \pm 5.8^{\mathrm{c}, \mathrm{d}}$ & $3.3 \pm 3.3^{\mathrm{a}}$ \\
\hline $\mathrm{T} 11$ & & 5 & $63.3 \pm 15.3^{\mathrm{a}, \mathrm{b}, \mathrm{c}, \mathrm{d}}$ & $33.3 \pm 11.5^{\text {a,b,c,d }}$ & $0.0^{\mathrm{a}}$ \\
\hline $\mathrm{T} 13$ & 15 & 15 & $60.0 \pm 10.0^{\mathrm{a}, \mathrm{b}, \mathrm{c}, \mathrm{d}}$ & $40.0 \pm 10.0^{\mathrm{a}, \mathrm{b}, \mathrm{c}, \mathrm{d}}$ & $0.0^{\mathrm{a}}$ \\
\hline $\mathrm{T} 14$ & & 20 & $50.0 \pm 10.0^{\mathrm{b}, \mathrm{c}, \mathrm{d}}$ & $50.0 \pm 10.0^{\mathrm{b}, \mathrm{c}, \mathrm{d}}$ & $10.0 \pm 5.8^{\mathrm{a}, \mathrm{b}}$ \\
\hline $\mathrm{T} 15$ & & 30 & $46.7 \pm 11.5^{\mathrm{b}, \mathrm{c}, \mathrm{d}}$ & $53.3 \pm 11.5^{c, d}$ & $23.3 \pm 8.8^{\mathrm{b}, \mathrm{c}}$ \\
\hline $\mathrm{T} 16$ & & 5 & $60.0 \pm 10.0^{\mathrm{a}, \mathrm{b}, \mathrm{c}}$ & $30.0 \pm 10.0^{\mathrm{a}, \mathrm{b}, \mathrm{c}}$ & $0.0^{\mathrm{a}}$ \\
\hline T17 & & 10 & $63.3 \pm 11.5^{\mathrm{a}, \mathrm{b}, \mathrm{c}, \mathrm{d}}$ & $36.7 \pm 11.5^{\mathrm{a}, \mathrm{b}, \mathrm{c}, \mathrm{d}}$ & $0.0^{\mathrm{a}}$ \\
\hline $\mathrm{T} 18$ & 20 & 15 & $16.7 \pm 5.8^{d}$ & $73.3 \pm 5.8^{, d}$ & $3.3 \pm 3.3^{\mathrm{a}}$ \\
\hline T19 & & 20 & $23.3 \pm 5.8^{\mathrm{c}, \mathrm{d}}$ & $56.7 \pm 5.8^{\mathrm{c}, \mathrm{d}}$ & $13.3 \pm 3.3^{\mathrm{a}, \mathrm{b}}$ \\
\hline $\mathrm{T} 20$ & & 30 & $13.3 \pm 5.8^{\mathrm{c}, \mathrm{d}}$ & $86.7 \pm 5.8^{\mathrm{c}, \mathrm{d}}$ & $33.3 \pm 8.8^{\mathrm{c}}$ \\
\hline
\end{tabular}

Data recorded in the mean with $n=30$ of the frequency of contamination and survival of explants after two weeks of culture. Data expressed in different upper case letters showed significantly different at $\mathrm{P}<0.05$ by Tukey's HSD test. (+) represents browning and (-) not browning.

Table 3. Callus induction of Dendrobium aurantiacum under different hormone treatment

\begin{tabular}{|c|c|c|c|c|c|c|c|}
\hline Treatment & $\begin{array}{c}\text { 2,4-D } \\
(\mathrm{mg} / \mathrm{L})\end{array}$ & $\begin{array}{c}\mathrm{KIN} \\
(\mathrm{mg} / \mathrm{L})\end{array}$ & $\begin{array}{c}\text { Callus } \\
\text { formation time } \\
\text { (days) }\end{array}$ & $\begin{array}{c}\text { Callus } \\
\text { induction rate } \\
(\%)\end{array}$ & $\begin{array}{l}\text { Callus } \\
\text { colour }\end{array}$ & Callus type & $\begin{array}{l}\text { Browning } \\
\text { condition }\end{array}$ \\
\hline A & - & - & 7 & 100 & white & $\begin{array}{l}\text { compact } \\
\text { hard }\end{array}$ & $0.00^{a}$ \\
\hline B & 1.0 & 0.5 & 5 & 100 & white & $\begin{array}{l}\text { compact } \\
\text { hard }\end{array}$ & $0.00^{\mathrm{a}}$ \\
\hline C & 10.0 & 0.0 & 3 & 100 & white & $\begin{array}{l}\text { compact } \\
\text { hard }\end{array}$ & $13.33^{b}$ \\
\hline
\end{tabular}

Data is presented in the mean with $n=5$ for callus browning condition. Data expressed in different upper case letters showed significantly different at $\mathrm{P}<0.05$ by Tukey's HSD test.

browning condition occurred in callus supplemented with treatment A and B but about $13.33 \%$ of callus on treatment $\mathrm{C}$ showed slight browning. Explant browning is mainly caused by the oxidation of phenolic compounds (19). However, the callus on treatment $\mathrm{C}$ with totipotency properties can continuous propagated in the agar media with multiple subculture in both solid and liquid MS culture media with appropriate hormone as designed in the experiment.

Plant hormone 2,4-Dichlorophenoxyacetic acid was invented in 1967 as the first synthetic herbicide that commonly used at high dose to control annual and perennial weeds (20). Since then, 2,4-D were also found to be useful in promoting cell elongation and division (21) and also plant responses for regeneration (22). Our result is in agreement that 10 $\mathrm{mg} / \mathrm{L}$ 2.4-D is the best auxin for enhancing callus induction, callus proliferation and subculture of grass (23). Research on in vitro regeneration of Dendrobium sp. (24) also reported that the maximum protocorm-like bodies (PLBs) formation (90\%) was observed in $10 \mathrm{mg} / \mathrm{L}$ 2, 4-D after 60 days of culture.

The combination of 2,4-D and kinetin is more effective for fresh weight and dry weight of shoot- derived callus, but 2,4-D alone is more effective in inducing callus growth (25). Results showed that callus induction occurred in both MS media with and without hormones, but the process is very slow in the MS media without hormone.

\section{Cell Count on Callus Proliferation}

To determine the callus cell proliferation, the changes in number of callus cell in the control and treatments were measured using cell counter. Callus cell concentration of on day 0 was $2.35 \times 10^{4}$ live cells per $\mathrm{ml}$. The orchid callus in treatment $\mathrm{C}$ media has the highest cell concentration with $43.73 \times 10^{6}$ live cells per ml, showed about 14-fold compared to treatment A media showed only $2.98 \times 10^{6}$ live cells per mL of callus cell concentration (Fig. 4).

\section{Somatic Embryogenesis}

Proliferated callus was transferred to MS medium with the supplement of $0.5 \mathrm{mg} / \mathrm{L} \mathrm{BAP}$ and $0.5 \mathrm{mg} / \mathrm{L}$ NAA hormone for regeneration. Fig. 5 showed the somatic embryogenesis of Dendrobium aurantiacum.

In orchids, somatic embryogenesis is part of the early steps of PLB regeneration (10) and can be divided into three stages: initial somatic embryo cell generation, globular somatic embryo formation and 


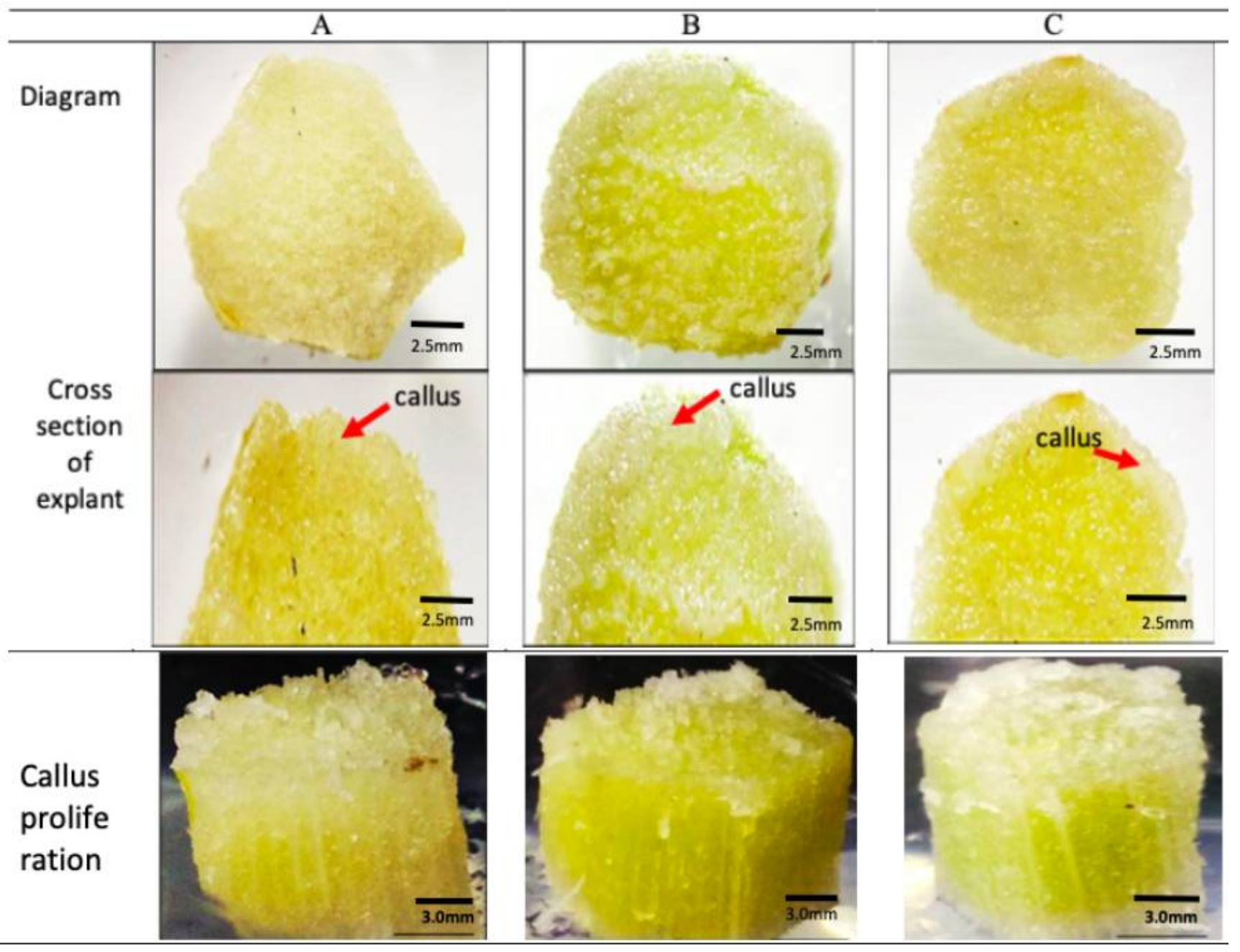

Fig. 3. Callus induction of Dendrobium aurantiacum treated with different hormone treatment. A is MS media without hormone supplement, B is MS media supplemented with $1.0 \mathrm{mg} / \mathrm{L} \mathrm{2,4-D}$ and $0.5 \mathrm{mg} / \mathrm{L} \mathrm{KIN}$, and C is Ms media supplemented with 10.0 mg/L 2,4-D.

a

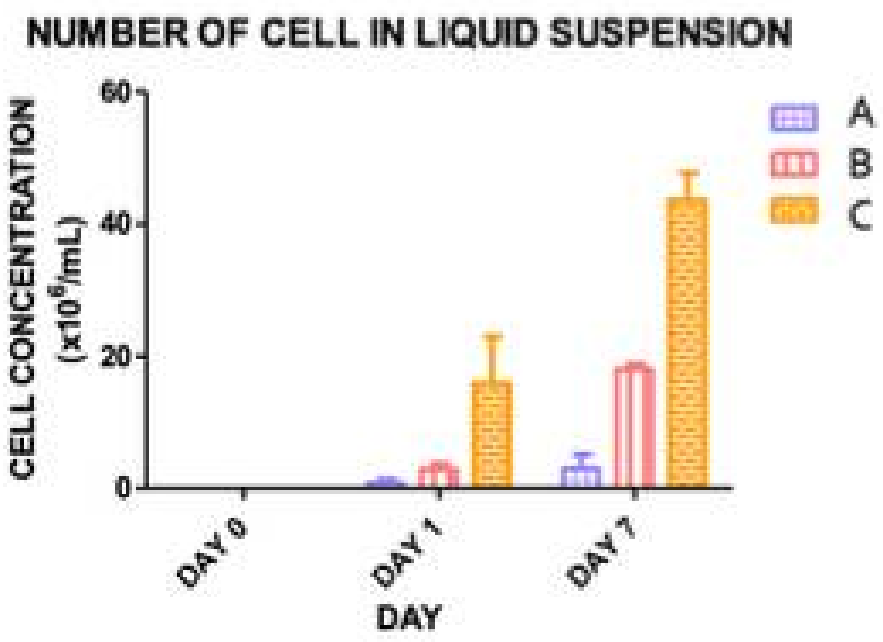

b

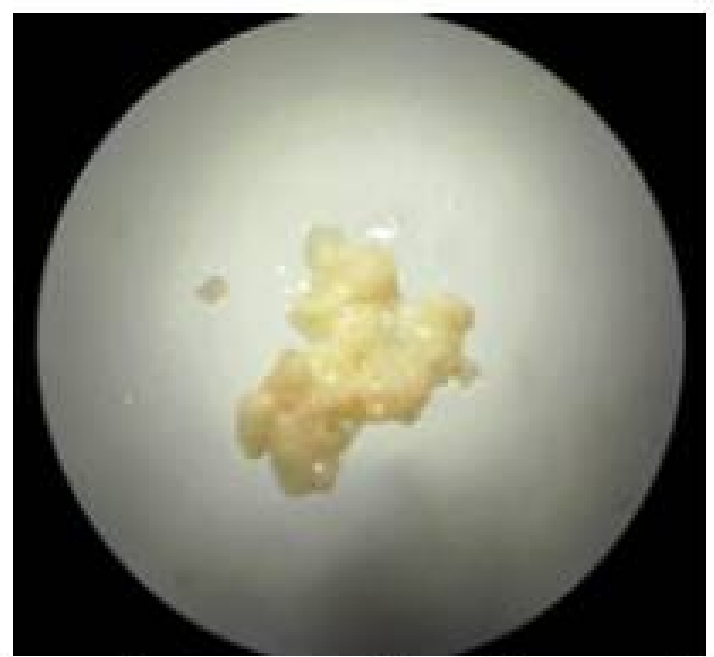

Fig. 4. Callus proliferation in liquid suspension culture. 4a represents the cell count of callus proliferation at Day 0,1 and 7 ; b represents the structure of callus proliferated in the treatment of $10 \mathrm{mg} / \mathrm{L}$ 2,4-D hormone medium.

somatic embryo differentiation (26). There are two pathways in somatic embryogenesis. First, single-cellderived somatic embryo is generated, develops into a globular somatic embryo similar to zygotic embryogenesis (27) which later become PLBs with shoot tip, and eventually develops into plantlets (10). The other is the production of multiple-cell-derived somatic embryos that directly form globular or multicellular somatic embryos, lacking the typical early stages of embryogenesis (27).

During the transition process, condensation and devacuolation occur continuously in the cytoplasm of embryogenic callus cells, and the cell fate changes (26), thereby forming an initial somatic embryo cell 


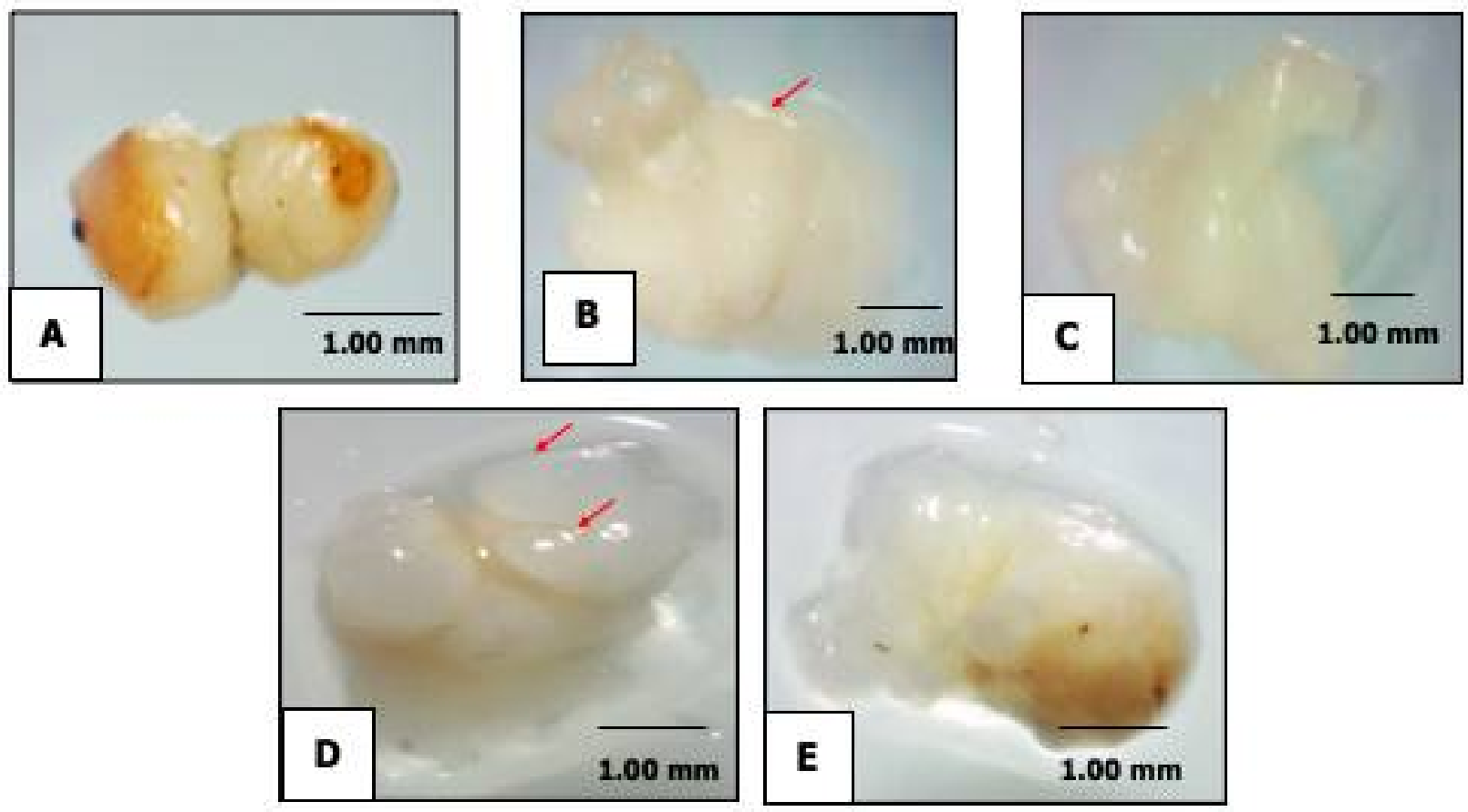

Fig. 5. The transformation of somatic embryos at different growth development stages of Dendrobium aurantiacum, where (A \& B) Globularshaped somatic embryo; (C) Heart-shaped somatic embryo; (D) Early torpedo-shaped embryo; (E) Torpedo-shaped of somatic embryo. Scale of magnification: (A) 50x, (B and C) 25x, (D and E) 32x.

composed of dense cytoplasm, a clear nucleus and small vacuoles (27). This process continues at various stages of differentiation and development, such as pro-embryo, globular, heart- shaped and torpedo embryos (28).

The orchid embryo is small with a reduced number of cells compared to other flowering plants (29). Therefore, their rate of cell division is slow, and the cell cycle time is long. The absence of a cotyledon is a common characteristic of orchid species (29). Several factors such as medium composition, genotypic properties, and explants used also affect processes associated with callus induction, embryonic differentiation and plant regeneration (30).

\section{Conclusion}

The development of orchid industry is required to meet up the annual rising demand for high quality and medicinally important materials. Therefore, the application of modern micropropagation technique and tissue culture laboratories can help to promote the development of orchid industry. This study provides a protocol for the establishment of $D$. aurantiacum. The sterilization efficiency of sodium hypochlorite has been tested on $D$. aurantiacum by using different concentration. Results showed that $20 \%$ sodium hypochlorite has the optimal sterilization effect with $83.33 \pm 5.8 \%$ of survival rate after 1 month and no browning condition. Callus induction were obtained in all plant hormones. Highest callus induction and proliferation was achieved in medium supplemented with $10 \mathrm{mg} / \mathrm{L} \mathrm{2,4-}$ D. High callus productions with effective micropropagation technique can create mass orchid market with uniform propagated plants. Further exploitation and conservation efforts on the valuable, endangered or rare species are essential for conservation and commercialization purposes. More efforts including standardized the protocols based on orchid species, phenology and habitat nature are required for the development of laboratory procedures and there by making the techniques more accessible and applicable to the local farmers and orchid developers.

\section{Acknowledgements}

Authors acknowledge Malaysia Toray Science Foundation (MTSF) for the financial support under Vot 53332. Special appreciation to Universiti Malaysia Terengganu and Microelectronics \& Nanotechnology Research Centre Institute for Integrated Engineering in Universiti Tun Hussein Onn Malaysia in providing the research platform to conduct the research.

\section{Authors' Contributions}

MYL constructed the experimental design and initial of the overall project, completed and finalized the whole manuscript. KSC carried out the optimization of sterilization technique in orchid, Dendrobium aurantiacum and drafted the manuscript. LJX performed the callus induction and proliferation data analysis. SCF and NAAS conceived the overall experimental design and study. All authors read and approved the final manuscript.

\section{Conflict of Interests}

There is no competing interest in this project. 


\section{References}

1. Hinsley A, de-Boer HJ, Fay MF, Gale SW, Gardiner LM, Gunasekara RS, Kumar P, Masters S, Metusala D, Roberts DL, Veldman S. A review of the trade in orchids and its implications for conservation. Bot J Linn Soc. 2017;186(4):43555. http://doi.org/10.1093/botlinnean/box083

2. Vaidya BN. Nepal: a global hotspot for medicinal orchids. In: Joshee N, Dhekney S, Parajuli P (editors). Med. Plant. Springer, Cham.2019. p. 35-80. http://doi.org/10.1007/978-3030-31269-5_3

3. Moudi M, Go R, Yien CYS, Saleh MN. A review on molecular systematics of the genus Dendrobium Sw. Acta Biol Malays. 2013;2(2)71-78. http://doi.org/10.7593/abm/2.2.71

4. Ying L, Jin H, Yan Z, Ye GC. Chemical constituents of Dendrobium aurantiacum var. denneanum. Chem Nat Compd. 2009;45(4):525.

5. Fang H, Hu X, Wang M, Wan W, Yang Q, Sun X, Chen CYO. Antiosmotic and antioxidant activities of gigantol from Dendrobium aurantiacum var. denneanum against cataractogenesis in galactosemic rats. J Ethnopharmacol. 2015;172:238-46. http://doi.org/10.1016/j.jep.2015.06.034

6. Yang L, Wang Y, Zhang G, Zhang F, Zhang Z, Wang Z, Xu L. Simultaneous quantitative and qualitative analysis of bioactive phenols in Dendrobium aurantiacum var. denneanum by highperformance liquid chromatography coupled with mass spectrometry and diode array detection. Biomed Chromatogr. 2017;21(7):687-94. http://doi.org/10.1002/bmc.801

7. Goh CJ, Arditti J. Orchidaceae. In: Halevy AH (editor). Handbook of Flowering Plants. Boca Raton, Florida: CRC Press. 1985. p. 309-36.

8. Rasmussen HN. Recent developments in the study of orchid mycorrhiza. Plant Soil. 2002;244(1-2):149-63. http://doi.org/10.1007/978-94-017-1284-2_15

9. da Silva ALL, Costa JDL, Gollo AL, Dos Santos JD, Forneck HR, Biasi LA, Soccol VT, De Carvalho JC, Soccol CR. Development of a vinasse culture medium for plant tissue culture. Pak J Bot 2014;46(6):2195.

10. Hussain A, Qarshi IA, Nazir H, Ullah I. Plant tissue culture: current status and opportunities. Recent Adv Plant In-vitro Cult. 2012;17:1-28. http://doi.org/10.5772/50568

11. Zhao P, Wu F, Feng FS, Wang WJ. Protocorm-like body (PLB) formation and plant regeneration from the callus culture of Dendrobium candidum Wall. ex Lindl. In Vitro Cell Dev Biol Plant. 2008;44(3):178. http://doi.org/10.1007/s11627-007-9101-2

12. National Centre of Biotechnology Information NCBI. Dendrobium denneanum [Dataset]. 2015 Oct 1 [cited by $2019 \mathrm{Ju}$ 3]. Available from: http:/www.ncbi.nlm.nih.gov/Taxonomy/Browser/wwwtax.cgi? lvl=0\&id=181002

13. Murashige T, Skoog F. A revised medium for rapid growth and bioassays with tobacco tissue cultures. Physiologia Plantarum. 1962;15:473-97. 3054.1962.tb08052.x http://doi.org/10.1111/j.1399-

14. Peiris SE, De Silva ED, Edussuriya M, Attanayake AMU, Peiris BCN. CSUP technique: a low-cost sterilization method using sodium hypochlorite to replace the use of expensive equipment in micropropagation. J Nat Sci Found. 2012;40:1. http://doi.org/10.4038/jnsfsr.v40i1.4168

15. Estrela C, Estrela CRA, Barbin EL, Marchesan JCMA, Pécora JD. Spanó E. Mechanism of action of Sodium hypochlorite. Braz
Dent J. 2002;13(2):113-17. http://doi.org/10.1590/S010364402002000200007

16. Leifert C, Waites WM. Dealing with microbial contaminants in plant tissue and cell culture: hazard analysis and critical control points. In: In Physiology, Growth and Development of Plants in Culture. Springer, Dordrecht. 1994. p. 363-78.

17. Rahman SME, Khan I, Oh DH. Electrolyzed water as a novel sanitizer in the food industry: current trends and future perspectives. Compr Rev Food Sci Food Saf. 2016;15(3):471-90. http://doi.org/10.1111/1541-4337.12200

18. Zulkepli AZ, Jaafar H, Rusni AHA. Optimization of sterilization method and callus induction of Salacca glabrescens. Int Proc Chem Biol Environ Eng. 2011;24:106-11.

19. Kumar KR, Singh KP, Raju DVS, Kumar P, Panwar S, Bhatia R. Circumventing phenolic exudation and poor survival in micropropagation of marigold. Hortic Soc India. 2018;75(2):273-78.

http://doi.org/10.5958/0974-0112.2018.00046.4

20. Peterson GE. The discovery and development of 2, 4-D. Agric Hist. 1967;41(3):243-54.

21. Song Y. Insight into the mode of action of 2, 4dichlorophenoxyacetic acid (2, 4-D) as a herbicide. J Integr Plant Biol. 2014;56(2):106-13. http://doi.org/10.1111/jipb.12131

22. Gaj MD. Factors influencing somatic embryogenesis induction and plant regeneration with particular reference to Arabidopsis thaliana (L.) Heynh. Plant Growth Regul. 2004;43(1):27-47.

http://doi.org/10.1023/B:GROW.0000038275.29262.fb

23. Chaudhury A, Qu R. Somatic embryogenesis and plant regeneration of turf-type bermudagrass: Effect of 6benzyladenine in callus induction medium. Plant Cell Tissue $\begin{array}{lll}\text { Organ } & \text { Cult. } & \text { 2000;60(2):113-20 }\end{array}$ http://doi.org/10.1023/A:1006456005961

24. Goswami K, Yasmin S, Nasiruddin KM, Khatun F, Akte J. In vitro regeneration of Dendrobium sp. of orchid using leaf tip as explant. J Environ Sci Nat Resourc. 2015;8(2):75-78 http://doi.org/10.3329/jesnr.v8i2.26869

25. Karimian R, Lahouti M, Davarpanah SJ. Effects of different concentrations of 2, 4-d and kinetin on callogenesis of Taxus brevifolia. Nut J Appl Biotechnol Rep. 2015;(4):167-70.

26. Cui Y, Zhao P, An H, Lu N, Zhang Z, Pei W, Wang W. Initiation and cytological aspects of somatic embryogenesis in Dendrobium candidum (Wall. ex Lindl). Hort Science. 2017;52(8):1111-16. http://doi.org/10.21273/HORTSCI10525-17

27. da Silva JAT, Winarto B. Somatic embryogenesis in two orchid genera (Cymbidium, Dendrobium). In: In vitro Embryogenesis in Higher Plants. Humana Press, New York; 2016. p. 371- 86 http://doi.org/10.1007/978-1-4939-3061-6_18

28. Magray MM, Wani KP, Chatt MA, Ummyiah HM. Synthetic seed technology. Int J Curr Microb Applied Sci. 2017; 6(11):662-74.

29. Yeung EC. A perspective on orchid seed and protocorm $\begin{array}{llll}\text { development. } & \text { Bot } & \text { Stud. } & \text { 2017;58(1):33 }\end{array}$ http://doi.org/10.1186/s40529-017-0188-4

30. Refish NMR, Wang L, Fu C, Xu X, Jin W, Li M, Yu L. Establishment and optimization of high efficiency embryogenic callus induction system in Dendrobium candidum. African J Plant Sci. 2016;10(4):77-83. http://doi.org/10.5897/AJPS2015.1389 